\title{
CERULOPLASMIN ACTIVITY AND ITS RELATION TO COPPER LEVEL IN BLOOD SERUM OF FRIESIAN DAIRY COWS.
}

\author{
GHADA A.E. MOHAMED; EMAN M.A. EL-NASER and HANAN K. ELSAYED* \\ *Dept. of Animal Med., Fac.of Vet. Med., Assiut Univ. Assiut. Egypt; Animal health Research Institute, Assiut, Egypt. \\ Email: $\underline{\text { dr kada2012@yahoo.com }}$
}

\section{ABSTRACT}

Received at: 25/12/2013

Accepted: 12/2/2014
The relationship between ceruloplasmin, a metalloenzyme with oxidase activity, and copper was investigated in Frisian dairy cows. The oxidase activity of ceruloplasmin correlated closely with the serum copper concentrations in Frisian dairy cows. Variations of copper $(\mathrm{Cu})$ concentration and ceruloplasmin $(\mathrm{Cp})$ activity in serum of dairy cows at different stages of lactation were assessed in 60 Frisian dairy cows. Furthermore, ceruloplasmin to copper ratios were also investigated. The cows were classified according to their lactation stages into three different groups as early lactation stage (4-6 weeks postpartum), midlactation stage (17-22 weeks postpartum) and late-lactation stage (25-30 weeks post-partum). Each group consisted of 20 multiparous cows. Serum samples were obtained from each cow for estimation of cereloplasmin activity and copper levels. Concentrations of serum copper $(\mathrm{sCu})$ were higher in the group of early lactation stage than the other groups $(\mathrm{P}<0.05)$. Serum cereloplasmin $(\mathrm{sCp})$ activity also showed significant difference between early lactation, mid and late lactation groups $(\mathrm{P}<0.05)$. The ratios of cereloplasmin activity to copper concentration $(\mathrm{Cp} / \mathrm{Cu})$ were significantly changed in the different lactation stages of dairy cows $(\mathrm{P}<0.05)$. For evaluation of copper status, use of $\mathrm{sCp} / \mathrm{sCu}$ identified more animals as 'low' and 'marginal'. It can be concluded that ceruloplasmin and copper undergo a physiological increase justafter calving; thus, their values should be interpreted with caution during assessment of copper status. Further research is required to refine diagnosis criteria for use of such ratio in determining copper status in Frisian dairy cows.

Key Words: dairy cow, lactation stages, copper, ceruloplasmin.

\section{INTRODUCTION}

Copper $(\mathrm{Cu})$ is one of the essential and important trace elements for the normal health and growth of animals (Rucker et al., 2008). Clinical copper deficiency occur as a primary deficiency due to lack of copper intake or as secondary deficiency due to inhibition of normal copper homeostasis by the antagonistic minerals as molybdenum, sulphur and iron (Suttle, 1991).

Copper has an important role in the immune system helping to fight off infections and diseases. Inadequate copper status may be related to an increased incidence of infections at calving. Serum copper concentration is a reliable indicator of copper deficiency (Weiss, 2010).

Ceruloplasmin $(\mathrm{Cp})$ is a metalloenzyme with oxidase activity that is associated with iron and copper homeostasis (Szczubiał et al., 2008). Each molecule of ceruloplasmin contains six to eight atoms of copper which influence its biological activity. Cereloplasmin has been used diagnostically to confirm copper deficiency (Laven and Livesey, 2007).

Ceruloplasmin ( $\mathrm{Cp}$ ) functions include transportation of copper in the blood to various tissues, oxidizing minerals most notably iron and manganese, and scavenging oxygen radicals to protect cells. Copper is involved in the antioxidant system through its presence in several significant proteins. Copper is present most commonly in the proteins ceruloplasmin and superoxide dismutase (SOD). Ceruloplasmin activity is diminished or absent without sufficient copper (Gropper et al., 2005).

Ceruloplasmin is released into the blood from the liver and constitutues about $60 \%$ of the circulating copper in the blood after meals (Smith and Cipriano, 1987) as a modulator of the inflammatory process; 
ceruloplasmin serves as anacute-phase protein. Acute phase proteins rise in the blood with infection and other inflammatory events (Ceron et al., 2005 and Gropper et al., 2005). Ceruloplasmin (Cp) evaluation gives an indication of the health status of cattle and could be used as a marker of animal health and welfare (Skinner et al., 2001 and Martinez-Subiela et al., 2002). The percentage of copper associated with ceruloplasmin was $55 \%$ in serum (Kincaid et al., 1986).

Laven, et al. (2007) used serum $\mathrm{Cp} /$ serum $\mathrm{Cu}(\mathrm{sCu})$ for evaluation of copper status in cattle as marginal and low. The lower end of the normal range for serum copper concentration is reported to be $10 \mu \mathrm{mol} / \mathrm{L}$, but serum copper concentrations were considerably lower than this when cases of copper deficiency were discovered (Laven et al., 2007). While serum copper concentration is an index of copper deficiency, it does not reflect dietary intake except when intake is below a certain level. Serum copper concentration increases under a number of conditions due to increased concentrations of ceruloplasmin (Mackenzie et al., 2001).

The aim of the present study was to evaluate the relationship between ceruloplasmin activity and copper concentration at three different stages of lactation in serum of dairy Friesian cows. Furthermore, ceruloplasmin to copper ratios was also investigated.

\section{MATERIALS and METHODS}

\begin{abstract}
Animals
A total number of 60 Friesian dairy cows were included in this study. All cows were classified randomly according to their lactation stages into three different groups as early (4-6 weeks post-partum), mid (17-22 weeks) and late (25-30 weeks) postpartum. The age of cows ranged from 4 to 7 years. Cows were clinically healthy, and any cows that had diseases such as lameness or mastitis were excluded from the study depending on the clinical examination made before the collection of blood samples (Skinner et al., 1991 and Horadagoda et al., 1999). The copper status of all cows was categorized according to their $\mathrm{Cp} / \mathrm{Cu}$ ratios into 'adequate', 'marginal' or 'low' as $>19,15-19$ or $<15 \mathrm{mg} / \mu \mathrm{mol}$, respectively, according to Telfer et al. (2004).
\end{abstract}

\section{Blood Sampling}

For separation of serum samples, blood samples were collected from each cow from the jugular vein into plane tubes without anticoagulants. The blood samples were left to clot, then centrifuged to provide non hemolysed serum and frozen at $-20^{\circ} \mathrm{C}$ until analysis.

\section{Biochemical Assays}

The activity of ceruloplasmin was measured by Assay Max Ceruloplasmin ELISAKit (Catalog No. EC40011 Assaypro) A polyclonal antibody specific for ceruloplasmin had been pre-coated into a specific microplate with removable strips. Ceruloplasmin in standards and samples is competed with a biotinylated ceruloplasmin sandwiched by the immobilized antibody and streptavidin- peroxidase conjugate. All unbound material was then washed away and a peroxidase enzyme substrate was added. The color development was stopped and the intensity of the color was measured. Serum was tested for copper using spectrophotometer (UV/ VIS spectrophotometer Optizem 3220 uv MECASYS Co., LTD, Korea.

\section{Statistical Analysis}

Values are presented as means \pm standard deviation (SD) of the mean. For statistical evaluations, all data were processed via the statistical package for social science (SPSS 2000). At first, analysis of variance was carried out to study the effects of lactation stage and sample type on concentrations of copper and activities of ceruloplasmin. The statistical significance of differences between group means was estimated by the least significant difference test at $\mathrm{P}<0.05$.

\section{RESULTS}

Table 1 showes concentrations of copper and activities of ceruloplasmin in serum and ceruloplasmin to copper ratios $(\mathrm{Cp} / \mathrm{Cu}$ ratios $)$ in different lactation stages included in the study. Serum copper $(\mathrm{Cu})$ concentrations were higher in the group of early lactation stage than the other groups in mid-lactation stage and late- lactation stage; the difference was significant $(\mathrm{P}<0.05)$. Serum ceruloplasmin $(\mathrm{Cp})$ activity was higher in the group of early lactation than the mid-lactation and late lactation stage groups $(\mathrm{P}<0.05)$; Lactation stage has significant effect on ceruloplasmin to copper ratios $(\mathrm{P}<0.05)$. 
Table 1: Effect of Lactation Stage on Mean Serum Copper Concentrations, Mean Serum Ceruloplasmin Activity, and mean $\mathrm{Cp} / \mathrm{Cu}$ ratio.

\begin{tabular}{|c|c|c|c|c|}
\hline & & $\begin{array}{c}\text { Early lactation } \\
\text { ( 4-6 w.p.p) }\end{array}$ & $\begin{array}{l}\text { Mid-lactation } \\
\text { ( 17-22 w.p.p) }\end{array}$ & $\begin{array}{l}\text { Late lactation } \\
\text { ( 25-30w.p.p) }\end{array}$ \\
\hline \multirow[t]{4}{*}{$\begin{array}{c}\text { Serum Cu } \\
(\mu \mathrm{mol} / \mathrm{l})\end{array}$} & $\begin{array}{l}\text { No. of cows in } \\
\text { each stage }\end{array}$ & 20 & 20 & 20 \\
\hline & Mean \pm SD & $21.55 \pm 1.74 *$ & $16.62 \pm 1.47^{*}$ & $9.7 \pm 1.9 *$ \\
\hline & Range & $19.2-24.8$ & $14.4-18.8$ & $7.0-13.2$ \\
\hline & $95 \% \mathrm{CI}$ & $20.38-22.73$ & $15.56-17.68$ & $8.3-11.0$ \\
\hline \multirow{4}{*}{$\begin{array}{c}\text { Serum } \\
\text { cereloplasmin } \\
\mathrm{Cp}(\mathrm{mg} / \mathrm{l})\end{array}$} & $\begin{array}{l}\text { No. of cows in } \\
\text { each stage }\end{array}$ & 20 & 20 & 20 \\
\hline & Mean \pm SD & $305.0 \pm 80.3^{*}$ & $183.3 \pm 19.4^{*}$ & $100.2 \pm 1.9 *$ \\
\hline & Range & $210-420$ & $150-210$ & $70.0-135.0$ \\
\hline & $95 \% \mathrm{CI}$ & $251.1-358.9$ & 169.4-197.2 & 84.4-115.9 \\
\hline \multirow[t]{4}{*}{$\begin{array}{c}\text { Serum Cp/Cu } \\
(\mathrm{mg} / \mu \mathrm{mol})\end{array}$} & $\begin{array}{l}\text { No. of cows in } \\
\text { each stage }\end{array}$ & 20 & 20 & 20 \\
\hline & Mean \pm SD & $14.18 \pm 4.0 *$ & $11.04 \pm 5.0 *$ & $10.30 \pm 48^{*}$ \\
\hline & Range & $13.9-16$ & $10.7-13.3$ & $9.7-12.0$ \\
\hline & $95 \% \mathrm{CI}$ & $13-16$ & $12-15$ & $9.3-13$ \\
\hline
\end{tabular}

* Different means in the same row differ significantly, $\mathrm{P}<0.05$, SD Standard deviation,

w.p.p. week(s) postpartum, CI confidence interval, $\mathrm{sCp} / \mathrm{sCu}$ serum ceruloplasmin to serum copper

Table 2 summarises the pooled data of the three groups' of lactation stages used in this study (early, mid and late) $\mathrm{Cu}$ concentrations and $\mathrm{Cp}$ activities in serum. Serum ceruloplasmin activity and $\mathrm{sCu}$ were significantly correlated $(\mathrm{r}=0.62$, $\mathrm{P}<0.01)$

Table 2: Values of Mean \pm SD, Number (n), range and 95\% CI of Pooled Data of Copper and Ceruloplasmin in serum.

\begin{tabular}{ccc}
\hline & Ceruloplasmin (mg/l) & Copper $(\boldsymbol{\mu m o l} / \mathbf{l})$ \\
\hline Number & 60 & 60 \\
\hline Mean \pm SD & $199.7 \pm 99.3$ & $21.55 \pm 5.2$ \\
\hline Range & $70.0-420.0$ & $7.0-24.8$ \\
\hline 95\% CI & $163.2-236.1$ & $14.2-18.06$ \\
\hline
\end{tabular}

Table 3 showes the copper status of dairy cows based on $\mathrm{sCp} / \mathrm{sCu}$, the use of $\mathrm{sCp} / \mathrm{sCu}$ identified more animals as marginal and low $(\mathrm{P}<0.001)$.

The copper status of all cows was categorized according to their $\mathrm{Cp} / \mathrm{Cu}$ ratios into 'adequate', 'marginal' or 'low' as $>19$, 1519 or $<15 \mathrm{mg} / \mu \mathrm{mol}$, respectively, according to Telfer, et al. (2004).

Table 3: Copper status of dairy cows based on serum $\mathrm{Cp} / \mathrm{serum} \mathrm{Cu}$ ratio.

\begin{tabular}{lccc}
\hline & \multicolumn{2}{c}{ Serum Cp/serum cu } \\
\cline { 3 - 4 } & & Marginal & low \\
\hline Number of all cows & 60 & 12 & 48 \\
& & & \\
\hline
\end{tabular}




\section{DISCUSSION}

The significant increase of ceruloplasmin activity in the group of early lactation suggested that parturition is associated with a physiologic acute response as a result of oxidative stress around calving, as has been described before (Koets et al., 1998; Castillo et al., 2005 and Hussein and Staufenbiel, 2012). Increased concentration of copper in the group of early lactation may be secondary to increased ceruloplasmin activity as most of copper is associated with this protein. Dairy cows undergoing stressful periods have physiologically increased blood levels of copper (Ward and Spears, 1999) and ceruloplasmin (Hussein et al., 2011).

Ceruloplasmin status should therefore be interpreted with caution in the days following parturition because it could be difficult to distinguish between the physiologic acute response of calving and a pathologic inflammatory process.

In comparison with those in plasma in the other researches recorded by (Paynter, 1982 and Kincaid et al., 1986), decreased copper concentrations and ceruloplasmin activities in serum might be due to trapping of some ceruloplasmin and its copper in the fibrin clot formation.

The low level of $\mathrm{sCp} / \mathrm{sCu}$ could be attributed to sequestration of ceruloplasmin and the copper associated with this protein into the clot during clot formation by attachment of the enzyme to the blood cellular fraction (Laven and Livesey, 2006).

Using $\mathrm{sCp} / \mathrm{sCu}$ in calculating $\mathrm{Cp} / \mathrm{Cu}$ ratio significantly altered individual sample status $(\mathrm{P}<0.001)$. Using $\mathrm{sCp} / \mathrm{sCu}$ identified more animals as low and marginal.

It can be concluded that, stage of lactation had a noticeable effect on the concentration of serum $\mathrm{Cu}$, and the lowest concentration was found within few weeks before dry off. The highest concentration was in the early stage of lactation and the levels in the mid-lactation varied (Laven et al., 2007). Concerning the serum ceruloplasmin activity, the obtained results revealed that there was a highly significant $(\mathrm{p} \leq 0.01)$ decrease in ceruloplasmin activity in -late lactationgroup. This finding offers diagnostic possibilities for copper deficiency.

\section{REFERENCES}

Castillo, C.; Hernandez, J. and Bravo, A. (2005): Oxidative status during late pregnancy and early lactation in dairy cows. Vet. J.; 169: 286-292.
Ceron, J.J.; Eckersall, P.D. and Martinez- Subiela, S. (2005): acute phase proteins in dogs and cats: current Knowledge and future perspectives. Vet ClinPathol 34: 85-99.

Gropper, S.S.; Smith, J. and Groff, J. (2005): Advanced Nutrition and Human Metabolism: Copper transport and uptake. $4^{\text {th }}$ ed. Wadsworth. Belmont, CA. 449-451.

Horadagoda, N.U; Knox, K.M. and Gibbs, H.A. (1999): Acute phase proteins in cattle: discrimination between acute and chronic inflammation. Vet. Rec. 144: 437-441.

Hussein, H.A.; Staufenbiel, $R$. and Müller, A.E. (2011): Ceruloplasmin activity in Holstein dairy cows: effects of lactation stages and anticoagulants. CompClinPathol. doi:10.1007/ s00580-010-1161-8.

Hussein, H.A. and Staufenbiel, R. (2012): Variations in Copper Concentration and Ceruloplasmin Activity of Dairy Cows in Relation to Lactation Stages with Regard to Ceruloplasmin to Copper Ratios. Biological Trace Element Research, 146, 1, p.47 (6).

Kincaid, R.L.; Gay, C.C. and Krieger, R.I. (1986): Relationship of serum and plasma copper and ceruloplasminconcentreations of cattle and the effect of whole blood sample storage. Amer J. Vet. Res. 47: 1157-1159.

Koets, A.; De Schartz, N. and Tooten, P. (1998): Release of proinflammatory cytokines related to luteolysis and the periparturient acute phase response in prostaglandin-induced parturition in cows. Theriogenology 49: 797-812.

Laven, R.A. and Livesey, C.T. (2006): An evaluation of the effect of clotting and processing of blood samples on the recovery of copper from bovine blood. Vet. J. 171: 295-300.

Laven, R.A. and Livesey, C.T. (2007): An evaluation of the effect of clotting on the relationship between copper and cereloplasmin in bovine blood. Vet. J. 174: 400- 402.

Laven, R.A.; Lawrence, K.E. and Livesey, C.T. (2007): The assessment of blood copper status in cattle: a comparison of measurements of caeruloplasmin and elemental copper in serum and plasma. New Zeal Vet. J. 55: 171-176.

Mackenzie, A.M.; Moeini, M.M. and Tefler, S.B. (2001): The effect of a copper, cobalt and selenium bolus on the fertility and trace element status of dairy cattle. Fertility in the high producing dairy cow. Brit SociAnimSci 26: 423-427.

Martinez-Subiela, S.; Tecles, F. and Montes, A. (2002): Effects of haemolysis, Lipaemia, bilirubinaemia and fibrinogen on protein electropherogram of canine samples analyses by capillary zone electrophoresis. Vet. J. 164: 261-268.

Paynter, D.I. (1982): Differences between serum and plasma ceruloplasmin activities and copper 
concentrations: investigation of possible contributing factors. Aust J BiolSci 35: 353-36

Rucker, R.B.; Fascetti, A.J. and Keen, C.L. (2008): Trace minerals, chapter biochemistry of domestic animals, $6^{\text {th }}$ edn. Academic Press, London, pp. 663-693.

Smith, J.E. and Cipriano, J.E. (1987): Inflammationinduced changes in serum iron analytes and ceruloplasmin of Shetland ponies. Vet. Pathol. 24: 354-356.

Suttle, N.F. (1991): The interactions between copper, molybdenum and sulphur in ruminant nutrition. Annu Rev Nutr 11: 121-140.

Skinner, J.G.; Brown, R.A and Roberts, L. (1991): Bovine haptoglobin response in clinically defined field conditions. Vet. Rec. 128: 147-149.

Skinner, J.G. (2001): Special report. International standardization of acute phase proteins. Vet. ClinPathol 30: 2-7.
Szczubiat, M.; Dąbroweski, R.; Kankofer, M. and Bochniarz, M; Albera, (2008): Concentration of serum amyloid A and activity of ceruloplasmin in milk from cows with clinical and subclinical mastitis. Bull Vet InstPulawy, 52: 391-395

SPSS (2000): Sample Power Statistics, SPSS 11.5, Syntax Reference Guide for SPSS Base. SPSS Inc., 233 South Wacker Drive, Chicago.

Telfer, S.B.; Kendall, N.R.; Illingworth, D.V. and Mackenzie, A.M. (2004): Molybdenum toxicity in cattle: an underestimated problem. Cattle Pract 12: 259-262

Ward, J. and Spears, J. (1999): The effect of lowcopper diets with or without supplemental molybdenum on specific immune responses of stressed cattle. J. Anim. Sci. 77: 230-237.

Weiss, W.P. (2010): Antioxidant nutrients and milk quality. Extension Americas Research based learning network. July, 19.

\section{نشاط السيريلوبلازمين وعلاقته بمستوى النحاس في مصل دم الأبقار الفريزيان الحلابة \\ غادة عبل العظيم محمد ، إيمان محمد عبد الناصر ، حنان كمال السبي \\ Email: dr kada2012@yahoo.com}

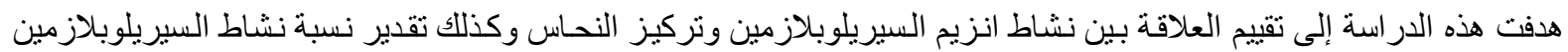

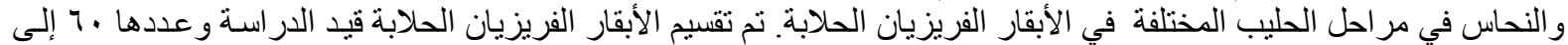

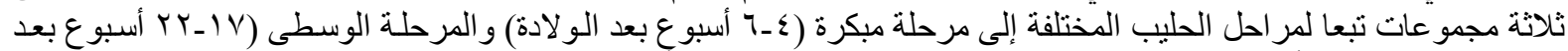

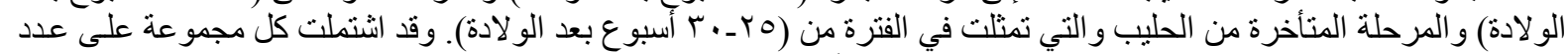

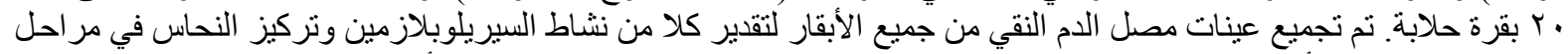

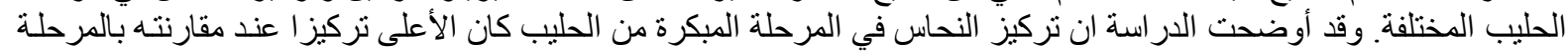

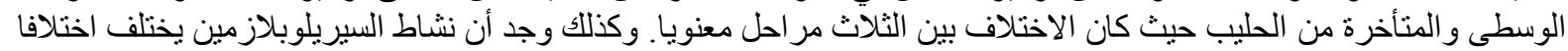

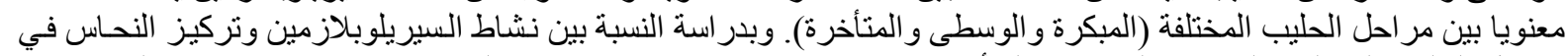

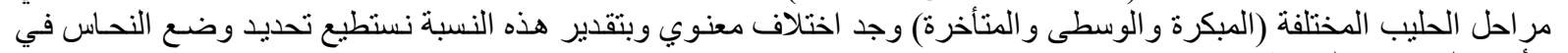
الأبقار الفريزيان الحلابة. 